\title{
BICRAL Gene
}

National Cancer Institute

\section{Source}

National Cancer Institute. BICRAL Gene. NCI Thesaurus. Code C157086.

This gene is involved in chromatin remodeling and transcriptional regulation. 